\title{
CHARACTERISTICS OF GLUTAMINE SYNTHETASE I AND II MUTANTS OF RHIZOBIUM
}

\author{
DONALD L. KEISTER, ${ }^{* * * *, 1}$ BENJAMIN L. JONES, ${ }^{* *, 2}$ \\ ADAM KONDOROSI, ${ }^{* * *}$ AND ZORA SVAB ${ }^{* * *, 3}$ \\ * Nitrogen Fixation and Soybean Genetics Laboratory, USDA, ARS, \\ BARC-W, Bldg. 011, HH-19, Beltsville, MD 20705 \\ ** Battelle-C. F. Kettering Research Laboratory Yellow Springs, \\ Ohio 45387 U.S.A. \\ *** Institute of Genetics, Hungarian Academy of Sciences, \\ H-6701 Szeged, Hungary
}

(Received March 3, 1987)

\begin{abstract}
Mutants of Rhizobium meliloti 41 and AK631 deficient in either glutamine synthetase I or II were characterized for growth and acetylene reduction activity. Comparison of the various mutants indicates that either GSI or GSII is competent to provide glutamine for cellular requirements with ammonia as the nitrogen source. The acetylene reduction activity of nodules induced by some $\mathrm{GSI}^{-}$or $\mathrm{GSII}^{-}$mutants was equal to the wildtype activity indicating that neither GS is required for symbiotic effectiveness and that either form is sufficient for effectiveness. No effect of purines on growth was found in the GS mutants of this strain.
\end{abstract}

Characteristic isoenzymes of glutamine synthetase (GS) are found in the Rhizobiaceae which includes Agrobacterium, Rhizobium and Bradyrhizobium (3$7,12,13)$. GSI has many properties similar to the GS found in enteric bacteria (3) while GSII appears solely in the Rhizobiaceae (7) and has properties distinctly different from $\operatorname{GSI}(3,4)$.

Ludwig (12,13), Morett et al.(14), and de Bruijn et al.(1) have isolated strains of Rhizobium and Bradyrhizobium which were $\mathrm{GSI}^{+} \mathrm{GSII}^{-}$illustrating that GSI alone is fully competent to supply the cell with glutamine. The competency of GSII to supply the cell with glutamine in B. japonicum 61A76 was supported by studies on the steady state kinetics of GSI and GSII (R. A. DARrow and R. R. KnOTTS, Abstracts of the 8th North American Rhizobium Conference, Univ. of

\footnotetext{
Address reprint requests to: Dr. Donald L. Keister, ${ }^{1}$ Present address: Nitrogen Fixation and Soybean Genetics Lab., USDA, ARS, BARC-W, HH-19, Beltsville, MD 20705, U.S.A.

${ }^{2}$ Present address: Campbell Institute for Research and Technology, Camden, NJ 08101, U.S.A.

${ }^{3}$ Present address: Advanced Genetic Sciences, Inc., 6701 San Pablo Ave., Oakland, CA 94608, U.S.A.
} 
Mannitoba, Winnipeg, Canada, 1981). These studies suggested that in fully derepressed cells, non-limited for ATP, over $90 \%$ of $\mathrm{NH}_{4}$ assimilation may be mediated by GSII. Recently the gene encoding GSI in $R$. meliloti(17) and $B$. japonicum (2) has been cloned. In $R$. meliloti, recombinants with an insertion in the GSI gene lose GSI activity, retain GSII activity, grow well on ammonia and are unaffected in nodulation and nitrogen fixation.

In this paper we will show that $\mathrm{GSII}^{-}$strains of $R$. meliloti 41 and AK631 and strains having very low GSI and near normal levels of GSII, are physiologically competent, illustrating that either isoenzyme can supply glutamine in this Rhizobium species.

LUDWIG (13) suggested that GSII in Bradyrhizobium sp. $32 \mathrm{Hl}$ may have a specific role in purine metabolism. The evidence presented was not strong and the data we will present in this paper do not support such a role for GSII. Thus, there is currently no satisfactory explanation for the presence of two catalytically active GS isoenzymes in the Rhizobiaceae.

\section{MATERIALS AND METHODS}

Stock cultures of $R$. meliloti were maintained on solid media containing glutamine and were grown in liquid medium as previously described (7) with nitrogen sources as noted. Cell growth was monitored by following the turbidity with a Klett-Summerson colorimeter. Cells were grown to mid-log phase, harvested and cell-free extracts prepared by disruption in a French pressure cell $(6,7)$. The $\gamma$ glutamyl transferase activity was measured using the assay with three buffers previously described $(5,6)$ and incubating for $15 \mathrm{~min}$ at $30^{\circ} \mathrm{C}$. The isoactivity point for the adenylylated and unadenylylated form of GSI in these studies was found to be $\mathrm{pH}$ 7.35. The levels of GSI and GSII were determined by their differential heat stability as described earlier $(6,7)$. The relative amount of adenylylated GSI was determined by the amount of inhibition of transferase activity caused by $60 \mathrm{~mm}$ $\mathrm{Mg}^{2+}$. From previous experience with $B$. japonicum, we are aware that the relationship between the percentage of magnesium inhibition and the adenylylation state as described for E. coli(18) does not necessarily hold for Rhizobium. Therefore, no attempt was made to calculate the $E_{\mathrm{n}}$ (adenylylation state).

Nodulation studies were carried out using alfalfa seedlings (variety Vernal). Seeds were sterilized for $10 \mathrm{~min}$ in commercial bleach to which one drop of Tween 20 has been added. After 10 washings with sterile distilled water, the seeds were transferred to $25 \times 200 \mathrm{~mm}$ test tubes, one-half filled with Turface. A comparison of Turface and vermiculite as substrate indicated that the plant roots have 2 to 4 times more nodules in Turface. The plants were watered with half-strength Jensen's medium (20) and allowed to germinate for 3 days. Before inoculation, seedlings were thinned leaving two per tube. After inoculation with a few drops of a liquid culture of $R$. meliloti, the plants were grown at $26^{\circ} \mathrm{C}$ in a growth cabinet on a $16 \mathrm{hr}$ light, $8 \mathrm{hr}$ dark cycle. After 18 to 28 days of growth, the tubes were capped with 
serum stoppers and $\mathrm{C}_{2} \mathrm{H}_{2}$ injected to $10 \%$. Samples $(0.25 \mathrm{ml})$ were removed with a syringe and ethylene was detected by gas chromatography as described previously (8).

\section{RESULTS AND DISCUSSION}

A compilation of the strains used, their phenotype and their parental strains is presented in Table 1. All strains retained GOGAT activity. In Table 2, the levels of GSII and GSI are shown as well as the ability of the adenylylation system(18) to respond to ammonia. AK598, AK 598R7, GY0516, ZS170, and ZS231 were GSII ${ }^{-}$, and AK598C41 had low GSII, while AK598C1 had moderate levels of GSII and a very reduced level of GSI. Of GSI, GY0516, AK598C41, AK598C44, and ZS231 had very reduced levels while AK598R7 had a moderate level. The adenylylation system of AK 598C1, which had a moderate level of GSII, appeared to be fully functional in its response to added ammonia, but none of the other mutants responded significantly. It is not known whether this is due to an impairment in the adenylylation system or to some regulatory mechanism which prevents adenylylation when only low levels of GS are present. The degree of adenylylation after prolonged growth in glutamine was similar to that after the ammonium shock.

The effect of adenine and guanine on the rate of growth of some of these strains in various nitrogen sources is shown in Table 3. As can be seen, adenine and guanine had little or no effect on the rate of growth of any of the strains used. Thus, these results do not support the role for GSII in purine biosynthesis previously proposed by LuDWIG (13). A conclusion similar to ours was reached by SHAH et al. (16). Also, if GSII were involved in the synthesis of purines, one might expect some repression of enzyme synthesis by the addition of purine. However, the addition of adenine

Table 1. Strains of $R$. meliloti.

\begin{tabular}{|c|c|c|c|c|}
\hline Strain & $\begin{array}{l}\text { Growth } \\
\text { phenotype }\end{array}$ & $\begin{array}{l}\text { Nodulation } \\
\text { phenotype }\end{array}$ & How selected & Reference \\
\hline 41 & wild-type & $\operatorname{Nod}^{+} \mathrm{Fix}^{+}$ & & (19) \\
\hline AK631 & wild-type & Nod $^{+} \mathrm{Fix}^{+}$ & small colony variant of 41 & $(11)$ \\
\hline Al & $\mathrm{His}^{-} \mathrm{Str}^{\mathrm{R}}$ & $\operatorname{Nod}^{+} \mathrm{Fix}^{+}$ & derivative of $R$. meliloti 41 & $(15)$ \\
\hline AK 598 & $\mathrm{His}^{-} \mathrm{Str}^{\mathrm{R}} \mathrm{Gln}^{-}$ & Nod $^{+} \mathrm{Fix}^{-}$ & NTG mutagenesis of Al & (9) \\
\hline AK 598R7 & $\mathrm{His}^{-} \mathrm{Str}^{\mathrm{R}} \mathrm{Gln}^{+}$ & $\operatorname{Nod}^{+} \mathrm{Fix}^{-}$ & spontaneous revertant of AK 598 & this paper \\
\hline AK $598 \mathrm{Cl}$ & $\mathrm{His}^{+} \mathrm{Gln}^{+}$ & $\mathrm{Nod}^{+} \mathrm{Fix}^{+}$ & recombinant of AK 598 carrying R68.45 & this paper \\
\hline AK 598C41 & $\mathrm{His}^{+} \mathrm{Gln}^{+}$ & Nod $^{+} \mathrm{Fix}^{-}$ & recombinant of AK 598 carrying R68.45 & this paper \\
\hline AK 598C44 & $\mathrm{His}^{+} \mathrm{Gln}^{+}$ & Nod $^{+} \mathrm{Fix}^{+}$ & recombinant of AK598 carrying R68.45 & this paper \\
\hline GY0516 & $\mathrm{Gln}^{-}$or Glt ${ }^{-}$ & $\operatorname{Nod}^{+} \mathrm{Fix}^{+}$ & NTG mutagenesis of AK631 & this paper \\
\hline ZS170 & $\mathrm{G} \ln ^{-}$ & $\operatorname{Nod}^{+} \mathrm{Fix}^{+}$ & NTG mutagenesis of AK631 & this paper \\
\hline ZS231 & $\mathrm{His}^{+} \mathrm{Gln}^{-}$ & $\operatorname{Nod}^{+} \mathrm{Fix}^{+}$ & derivative of $\mathrm{Al}$ & this paper \\
\hline ZS231C11 & $\mathrm{His}^{+} \mathrm{Gln}^{+}$ & Nod $^{+}$Fix $^{+}$ & recombinant of ZS231 & this paper \\
\hline
\end{tabular}

$\mathrm{Str}^{\mathrm{R}}$, streptomycin resistant; NTG, N-methyl-N'-nitro-N-nitrosoguanidine. Recombinants were constructed by mobilizing the $R$. meliloti chromosome using R68.45 (10). 
Table 2. GSI and GSII in $R$. meliloti strains. $^{a}$

\begin{tabular}{|c|c|c|c|c|c|}
\hline \multirow{3}{*}{ Strain } & \multirow{3}{*}{$\begin{array}{c}\text { Ammonia } \\
\text { shock }^{b}\end{array}$} & \multicolumn{3}{|c|}{ Transferase activity } & \multirow{3}{*}{$\begin{array}{c}\% \mathrm{Mg} \\
\text { Inhibition }\end{array}$} \\
\hline & & GSII & GSI & $\mathrm{GSI}+\mathrm{Mg}^{2+}$ & \\
\hline & & \multicolumn{3}{|c|}{$\mathrm{nmol} \min ^{-1} \mathrm{mg}$ protein ${ }^{-1}$} & \\
\hline \multirow[t]{2}{*}{ AK631 } & - & 1203 & 740 & 840 & -14 \\
\hline & + & 1332 & 890 & 115 & 87 \\
\hline AK 598 & - & $0^{c}$ & 86 & & \\
\hline \multirow[t]{2}{*}{ AK598R7 } & - & 0 & 360 & 303 & 16 \\
\hline & + & 0 & 376 & 255 & 32 \\
\hline \multirow[t]{2}{*}{ AK $598 \mathrm{Cl}$} & - & 640 & 130 & 126 & 0 \\
\hline & + & 655 & 164 & 41 & 75 \\
\hline \multirow[t]{2}{*}{ AK 598C41 } & - & 304 & 130 & 138 & -6 \\
\hline & + & 289 & 146 & 107 & 27 \\
\hline AK598C44 & - & 600 & 75 & & \\
\hline GY0516 & - & 0 & 140 & & \\
\hline $\mathrm{ZS} 170$ & - & 0 & 160 & $d$ & \\
\hline \multirow[t]{2}{*}{ ZS231 } & - & 0 & 156 & 135 & 13 \\
\hline & + & 0 & 141 & 109 & 23 \\
\hline $\mathrm{ZS} 231 \mathrm{C} 11$ & - & 0 & 600 & & \\
\hline
\end{tabular}

a Cells were grown in synthetic medium containing mannitol as the carbon source and glutamate $(0.1 \%)$ as the nitrogen source. For strains AK598 and AK598R7, 0.015\% histidine was also present.

b $10 \mathrm{mM} \mathrm{NH}_{4} \mathrm{Cl}$ was added to the culture $15 \mathrm{~min}$ prior to harvest.

c Differential heat sensitivity was used to determine GSI and II. Very small amounts are not easily determined using this assay. Thus, an activity less than 10 is considered zero.

${ }^{d}$ ZS170 and a few strains not reported here were markedly stimulated by $\mathrm{Mg}^{2+}$ before and after ammonia shock. The stimulation was removed by treating the extracts with deoxyribonuclease. Thus, it may be related to DNA binding of GSI. We have not pursued this observation.

and guanine to a culture of any of the strains of $R$. meliloti described in this paper had no effect on the levels of GSII (when present), on the levels of GSI, or on the adenylylation state of GSI (data not shown).

Based on these studies with $R$. meliloti it would appear that there is no specialized role for GSII in purine synthesis. Rather, based on the kinetic properties of the two GSs, DARrow has postulated that GSII is likely to serve as the major pathway of glutamine synthesis in the cells (R. A. DARrow and R. R. KNotTs, Absts. 8th North American Rhizobium Conference, Winnipeg, Canada, 1981).

\section{Growth studies with mutant strains}

Growth studies using a variety of nitrogen sources and strains representing several GS phenotypes are presented in Table 4. The wild-type strain (AK631) grows well on a variety of nitrogenous compounds. The mutants having low GSI and no GSII (GY0516, ZS170, and ZS231) grow slowly on $\mathrm{NH}_{4}$ and grow on $\mathrm{NO}_{3}$ only after a long lag phase. A recombinant of ZS231 (ZS231C11) with an increased amount of GSI grows well on all of the nitrogen sources including $\mathrm{NH}_{4}^{+}$. Mutants 
Table 3. Effect of purines on R. meliloti strains. ${ }^{a}$

\begin{tabular}{|c|c|c|c|c|}
\hline Strain & $\begin{array}{l}\text { Nitrogen } \\
\text { source }\end{array}$ & $\begin{array}{l}\text { Adenine plus } \\
\text { guanine } \\
(0.04 \mathrm{~mm} \text { each })\end{array}$ & $\begin{array}{c}\text { Generation } \\
\text { time (hr) }\end{array}$ & $\begin{array}{c}\text { GS } \\
\text { phenotype }\end{array}$ \\
\hline \multirow[t]{4}{*}{ AK631 } & $\mathrm{Glt}^{b}$ & - & 2.9 & wild-type \\
\hline & & + & 3.0 & \\
\hline & $\mathrm{NH}_{4} \mathrm{Cl}$ & - & 2.7 & \\
\hline & & + & 2.7 & \\
\hline \multirow[t]{2}{*}{ AK 598R7 } & $\mathrm{NH}_{4} \mathrm{Cl}$ & - & 3.9 & $\mathrm{GSII}^{-}$ \\
\hline & & + & 3.9 & \\
\hline \multirow[t]{2}{*}{ AK $598 \mathrm{Cl}$} & $\mathrm{NH}_{4} \mathrm{Cl}$ & - & 5.6 & $\mathrm{GSII}^{+}$, low GSI \\
\hline & & + & 5.8 & \\
\hline \multirow[t]{2}{*}{ AK 598C41 } & Glt & - & 6.3 & low GSII and GSI \\
\hline & & + & 6.6 & \\
\hline \multirow[t]{2}{*}{ AK 598C44 } & $\mathrm{NH}_{4} \mathrm{Cl}$ & - & 6.0 & $\mathrm{GSI}^{-}$ \\
\hline & & + & 5.9 & \\
\hline \multirow[t]{2}{*}{ GY0516 } & $\mathrm{NH}_{4} \mathrm{Cl}$ & - & 8.1 & $\mathrm{GSII}^{-}$, low GSI \\
\hline & & + & 7.6 & \\
\hline \multirow[t]{2}{*}{ ZS170 } & Glt & - & 4.1 & $\mathrm{GSII}^{-}$, low GSI \\
\hline & & + & 4.0 & \\
\hline \multirow[t]{2}{*}{ ZS231 } & $\mathrm{NH}_{4} \mathrm{Cl}$ & - & 6.6 & low GSI \\
\hline & & + & 6.9 & \\
\hline
\end{tabular}

a Cells were grown in the medium described for $R$. meliloti (7) with $25 \mathrm{~mm} 3$-(N-morpholino) propanesulfonic acid buffer and $0.5 \%$ mannitol as the carbon source.

${ }_{b}$ Glt, glutamate, $6 \mathrm{~mm} ; \mathrm{NH}_{4} \mathrm{Cl}, 15 \mathrm{~mm}$.

Table 4. Growth characteristics of GS mutants. ${ }^{a}$

\begin{tabular}{lrrrrrrrr}
\hline \multirow{2}{*}{ Strain } & \multicolumn{7}{c}{ Nitrogen source generation time (hr) } \\
\cline { 2 - 9 } & Gln & Glt & His & Asp & Pro & Arg & $\mathrm{NH}_{4}^{+}$ & $\mathrm{NO}_{3}^{-}$ \\
\hline AK631 & 3.3 & 3.5 & 3.3 & 3.8 & 4.4 & 6.7 & 3.3 & 4.8 \\
GY0516 & 4.7 & 4.7 & 5.0 & 9.1 & 6.0 & 6.6 & 11.6 & $b$ \\
ZS170 & 3.6 & 3.9 & 4.0 & 4.8 & 4.6 & 8.3 & 10.0 & $b$ \\
ZS231 & 7.1 & 6.1 & 6.7 & 9.8 & 7.6 & 8.5 & 13.4 & $b$ \\
ZS231C11 & 3.5 & 3.8 & 3.6 & 5.5 & 4.8 & 6.1 & 4.5 & 5.1 \\
AK598C41 & 4.9 & 5.4 & 5.7 & 6.8 & 7.0 & 6.8 & 6.9 & $b$ \\
AK598C1 & 4.3 & 4.4 & 4.5 & 4.9 & 4.9 & 6.6 & 5.9 & 5.3 \\
AK598C44 & 6.6 & 11.2 & 6.7 & 9.5 & 13.2 & 13.6 & 7.5 & 11.0 \\
\hline
\end{tabular}

a See Table 3 for growth medium. Nitrogen sources were as follows: gln, $\mathrm{NH}_{4}{ }^{+}$(as ammonium sulfate) and his, $5 \mathrm{~mm}$; all others, $10 \mathrm{~mm}$.

$b$ Growth occurs after a long lag period.

with low GSI and moderate levels of GSII (AK598C41, AK 598C44, and AK 598C1) grow on $\mathrm{NH}_{4}^{+}$and $\mathrm{NO}_{3}^{-}$although not as well as the wild type strain. $\mathrm{AK} 598 \mathrm{Cl}$ and AK 598C44 have GSI levels equal to or only slightly greater than their $\mathrm{Gln}^{-}$parent, 
Table 5. Acetylene reduction activity of nodulated plants. ${ }^{a}$

\begin{tabular}{|c|c|c|c|}
\hline \multirow{2}{*}{ Strain } & \multicolumn{2}{|c|}{$\begin{array}{l}\mathrm{C}_{2} \mathrm{H}_{2} \text { Reduction } \\
\mathrm{nmol} \mathrm{hr}{ }^{-1} \text { plant }^{-1}\end{array}$} & \multirow{2}{*}{ Nodules/plant } \\
\hline & 18 days & 28 days & \\
\hline AK631 & 950 & 1530 & $45 \pm 20$ \\
\hline GY0516 & 690 & 1500 & $57 \pm 33$ \\
\hline ZS170 & 870 & 1450 & $59 \pm 26$ \\
\hline ZS231 & 490 & 440 & $95 \pm 42$ \\
\hline ZS231C11 & 120 & 750 & $88 \pm 26$ \\
\hline AK $598 \mathrm{Cl}$ & 770 & 660 & $103 \pm 45$ \\
\hline AK598C41 & - & - & $59 \pm 28$ \\
\hline AK 598C44 & 800 & 1410 & $101 \pm 46$ \\
\hline
\end{tabular}

a The results of the nodulation studies are the average of at least three separate experiments with at least six plants per experiment. That the inoculated strain could be recovered from nodules was demonstrated with strains GY0516, ZS170, AK 598C1, and AK598C44. A nodule was selected at random from six separate plants. They were surface sterilized, crushed and streaked on agar plates. A colony was selected and cultured and the GS was determined. All colonies retained the original phenotype.

AK598. Thus, both GSI and GSII appear competent to supply the cell with glutamine.

\section{Nodulation studies}

The effectiveness of nodules as determined by $\mathrm{C}_{2} \mathrm{H}_{2}$ reduction with intact plants is shown in Table 5. These results show that strains with only low amounts of GSI are fully effective (GY0516 and ZS170), and that a strain with predominantly GSII (AK598C44) was also fully effective. This latter recombinant strain has GSI activity no higher than the mutant parent (AK 598). Although not recorded herein, the biosynthetic activity of the small amount of GSI of AK598C44 was found to be less than $20 \%$ of the biosynthetic activity expected for an equivalent amount of GSI activity in the wild type based on the transferase assay. Thus, the actual synthetic capacity of GSI from this strain is negligible. These results suggest that the catalytic activity of either GSI or GSII is sufficient to provide the bacterial cell with enough glutamine for the transition from free living to symbiotic function and that neither GSI nor GSII specifically, is required to sustain an effective symbiosis.

We thank Sarah S. Marsh for excellent technical assistance and Dr. Robert Darrow for many helpful suggestions. This work was supported in part by grant PCM 78-06672 from the National Science Foundation.

\section{REFERENCES}

1) F. J. de Bruijn, S. Rossbach, and J. Schell, In Nitrogen Fixation Research Progress, ed. by H. J. Evans, P. J. Bottomley, and W. E. Newton, Martinus Nijhoff, Dordrecht (1985), p. 218.

2) T. A. Carlson, M. L. Guerinot, and B. K. Chelm, J. Bacteriol., 162, 698 (1985). 
3) R. A. Darrow, In Glutamine: Metabolism, Enzymology and Regulation, ed. by J. Mora and R. Palacios, Academic Press, New York (1980), p. 139.

4) R. A. Darrow, D. Crist, W. R. Evans, B. L. Jones, D. L. Keister, and R. R. Knotts, In Current Perspectives in Nitrogen Fixation, ed. by A. H. Gibson and W. E. Newton, Australian Academy of Sciences, Canberra (1981), p. 182.

5) R. A. Darrow and R. R. Knotts, Biochem. Biophys. Res. Commun., 78, 554 (1977).

6) R. L. Fuchs and D. L. Keister, J. Bacteriol., 141, 996 (1980).

7) R. L. Fuchs and D. L. Keister, J. Bacteriol., 144, 641 (1980).

8) D. L. Keister and W. R. Evans, J. Bacteriol., 129, 149 (1976).

9) A. Kondorosi, Z. Svab, G. B. Kiss, and R. A. Dixon, Mol. Gen. Genet., 151, 221 (1977).

10) A. Kondorosi, G. B. Kiss, T. Forrai, E. Vincze, and Z. Banfalvi, Nature, 268, 525 (1977).

11) A. Kondorosi, E. Kondorosi, C. E. Pankhurst, W. J. Broughton, and Z. Banfalvi, Mol. Gen. Genet., 188, 433 (1982).

12) R. A. Ludwig, Proc. Natl. Acad. Sci. U.S.A., 77, 5817 (1980).

13) R. A. Ludwig, J. Bacteriol., 54, 1049 (1980).

14) E. Morett, S. Moreno, and G. Espin, Mol. Gen. Genet., 200, 229 (1985).

15) L. Orosz and T. SIK, Acta Microbiol. Acad. Sci. Hung., 17, 185 (1970).

16) K. Shah, S. Vanchiswar, and V. V. Modi, Curr. Sci., 54, 1049 (1985).

17) J. E. Somerville and M. L. Kahn, J. Bacteriol., 156, 168 (1983).

18) E. R. Stadman, A. Ginsburg, J. E. Ciardi, J. Yeh, S. Henning, and B. M. Shapiro, $A d v$. Enz. Reg., 8, 99 (1970).

19) K. Szende and F. Ordough, Naturwissenschaften, 47, 404 (1970).

20) J. M. Vincent, A Manual for the Practical Study of Root Nodule Bacteria, Blackwell Scientific Publication, Oxford (1970). 